\title{
The Dynamics of Macro- and Micronutrients in Native Tree Species Affected by Copper Contamination
}

\author{
Matheus Casarini Siqueira ${ }^{1}$ \\ Shoey Kanashiro ${ }^{1}$ \\ Marisa Domingos ${ }^{1}$ \\ Mirian Cilene Spasiani Rinaldi ${ }^{1}$ \\ Armando Reis Tavares ${ }^{1}$ (ic) \\ ${ }^{1}$ Instituto de Botânica de São Paulo, São Paulo, SP, Brasil.
}

\begin{abstract}
This study was conducted to assess the physicochemical characteristics of urban forest soil contaminated by copper and the dynamics of macro- and micronutrients uptake by Schinus terebinthifolia and Eugenia uniflora seedlings. The seedlings received 0 (control), 60, 120, 180 or $240 \mathrm{mg} \mathrm{Cu} \mathrm{kg}^{-1}$ soil applied to urban forest soil within São Paulo City, Brazil. Our results showed that $\mathrm{K}$ was reduced in $\mathrm{Cu}$-contaminated soil used for S. terebinthifolia cultivation and that organic matter was higher in $\mathrm{Cu}$ - contaminated soil used for E. uniflora cultivation. Other physicochemical properties of soil remained unaltered. S. terebinthifolia presented nutritional imbalances in $\mathrm{N}, \mathrm{K}$ and $\mathrm{Mg}$ on leaves, while E. uniflora presented nutritional imbalances in $\mathrm{K}$ on leaves and in $\mathrm{S}$ on roots. It can be concluded that copper contamination can negatively affect chemical and nutritional characteristics of urban forest soil, as well as the nutritional dynamics of $S$. terebinthifolia and E. uniflora.
\end{abstract}

Keywords: Schinus terebinthifolia, Eugenia uniflora, pollution, heavy metal, nutrition.

\section{INTRODUCTION AND OBJECTIVES}

Copper $(\mathrm{Cu})$ is an essential micronutrient for plant growth and development, playing key roles in several physiological processes, such as cell respiration, photosynthesis, ATP generation (Marques et al., 2018), participation in redox reactions and in oxidative stress protection (Rehman et al., 2019). Despite its necessity, copper in high concentrations can be toxic to plants, inducing adverse effects on plant physiology and biochemistry, such as excessive formation of reactive oxygen species (ROS) (Saleem et al., 2020), nutritional imbalance (Zeng et al., 2019), reduced growth and morphological alterations (Hossain et al., 2020).

Many factors influence the uptake of nutrients by terrestrial plants, such as temperature, $\mathrm{pH}$ and aeration of soils, organic matter, and soil contaminated with heavy metals (Hu et al., 2018). In general, excess copper in soil can disrupt plant nutritional metabolism by inhibiting the uptake of nutrients from soil and interfering with nutrient translocation from roots to shoots (Kumar et al., 2020). However, the degree of nutritional imbalance caused by $\mathrm{Cu}$ toxicity in plants is dependent on environmental factors, including the concentration and bioavailability of $\mathrm{Cu}$ in soil, length of exposure to heavy metal, and environmental growth conditions, as well as the morphophysiological characteristics of each plant species (Adrees et al., 2015).

In recent years, the accumulation of copper in soils has become a worldwide environmental concern. Human activities like mining, excessive use of copper-based pesticides, chemical and organic fertilizers, untreated sewage sludge and combustion of fossil fuels increase copper levels in soils, reaching concentrations that present risks for the biota and human health (Farias et al., 2018; Shabbir et al., 2020). Toxic concentration of $\mathrm{Cu}$ can be observed in highly urbanized regions, such as large cities, compared to more forested areas or areas with native vegetation, such as urban forest fragments (Argyraki et al., 2018; Li et al., 2019). Urban forest fragments are remnants of native and secondary forests inserted in the urban environment. These fragments play a specific role in the existence and long-term maintenance of ecosystem services, conservation of biodiversity and habitat for several plant species (Dislich \& Pivelo, 2002). However, the sheer proximity of various pollutants places urban forest fragments at risk of particulate material from the emissions of automotive fleets 
and industry. These emissions contain heavy metals and can contaminate both soil and ground water (Nakazato et al., 2021; Ferreira et al., 2019). Air pollution and deposition of particulate matter from human activities can also negatively affect the nutritional status of trees, reducing their development in urban forest remnants (Bulbovas et al., 2020).

Studies with tree species have already reported that excess copper in soil can negatively affect plant growth (Marco et al., 2016) and biomass production (Siqueira et al., 2021). It can also lower $\mathrm{CO}_{2}$ assimilation by reduced efficiency of the electron transport chain (Li et al., 2019). However, the direct effects of copper contamination on urban forest fragment soils, as well as the nutritional consequences observed in Brazilian native tree species from the Atlantic Forest cultivated in polluted soil, remain under investigated. It is herein hypothesized that the addition of increasing concentrations of copper in the soil of an urban forest fragment will alter its nutritional characteristics, thereby affecting the bioavailability of other elements, such as K or $\mathrm{Mg}$, triggering nutritional imbalance in tree species. Therefore, this study aimed to validate if copper contamination changes the physicochemical properties of experimental plots of urban forest fragment in a manner that directly affects the nutritional dynamics of two tree species native to the Atlantic Forest.

\section{MATERIALS AND METHODS}

\subsection{Characterization of plants and soil}

Soil used in the experiment (Table 1) was a red-yellow latosol (LVA) (Santos et al., 2018) collected between 0.0 and $40.0 \mathrm{~cm}$ in depth in a forest area in the Parque Estadual Fonte dos Ipiranga (PEFI), São Paulo City, São Paulo State, Brazil. The experiment was carried out in a greenhouse at

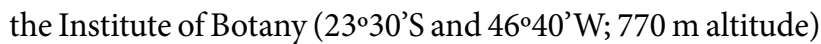
located inside the PEFI. Seedlings of the pioneer tree species Schinus terebinthifolia Raddi. (aroeira-vermelha) and the non-pioneer tree species Eugenia uniflora L. (pitanga), both native to the Atlantic Forest, were used in the experiment.

Table 1. Soil chemical composition at the beginning of the experimentation.

\begin{tabular}{|c|c|c|c|c|c|c|c|c|c|c|c|c|c|c|}
\hline $\mathrm{pH}$ & O.M. & $\mathbf{P}_{\text {resin }}$ & $\mathrm{H}+\mathrm{Al}$ & $\mathbf{K}$ & $\mathrm{Ca}$ & $\mathrm{Mg}$ & BS & CEC & \multirow{2}{*}{ V\% } & B & $\mathrm{Cu}$ & $\mathrm{Fe}$ & Mn & $\mathrm{Zn}$ \\
\hline $\mathrm{CaCl}_{2}$ & $\mathrm{~g} \mathrm{dm}^{3}$ & $\mathrm{mg} \mathrm{dm}^{3}$ & \multicolumn{6}{|c|}{$\mathrm{mmol}_{c} \mathrm{dm}^{-3}$} & & \multicolumn{5}{|c|}{$\mathrm{mmol}_{\mathrm{c}} \mathrm{dm}^{-3}$} \\
\hline 5.1 & 42.0 & 5.5 & 33.6 & 1.6 & 50.7 & 9.6 & 61.9 & 95.5 & 64.8 & 0.6 & 1.3 & 25.7 & 21.3 & 9.0 \\
\hline
\end{tabular}

Base summatory $(\mathrm{BS})=\mathrm{K}+\mathrm{Ca}+\mathrm{Mg}$; Cation exchange capacity $(\mathrm{CEC})=\mathrm{Ca}+\mathrm{Mg}+\mathrm{K}+\mathrm{Al}+\mathrm{H}$; Base saturation $(\mathrm{V} \%)=\mathrm{BS} / \mathrm{CEC}^{*} 100$

\subsection{Experimental conditions and design}

The seedlings were transplanted into $2.6 \mathrm{~L}$ vases containing natural PEFI soil and remained there for 30 days to allow acclimatization. The experiment consisted of the application of $75 \mathrm{ml}$ Hoagland and Arnon solution n.1. (Hoagland \& Arnon, 1950) modified with 0 (control), 60, 120, 180 or 240 mg Cu $\left(\mathrm{CuSO}_{4} \cdot 5 \mathrm{H}_{2} \mathrm{O}\right) \mathrm{kg}^{-1}$ soil dry weight (DW) (Table 2). Copper concentrations were based on the Environmental Agency of São Paulo State (CETESB, 2016) prevention value for $\mathrm{Cu}\left(60 \mathrm{mg} \mathrm{Cu} \mathrm{kg}{ }^{-1} \mathrm{DW}\right.$ soil). Ionic balance of the solutions was carried out in order to maintain the constancy of the other macro- and micronutrients, and $\mathrm{pH}$ was adjusted to 5.8 . The plants were irrigated weekly with $1 / 4$ of the total concentration, repeating the procedure 4 times to obtain the total values of copper in the soil for each treatment. During the experimental period, distilled water was used to irrigate the plants whenever necessary. The experiment lasted 120 days after soil contamination with copper between the spring and summer seasons in Brazil (September to December 2019) with a mean temperature of $26^{\circ} \mathrm{C}$ and relative humidity of $56 \%$ inside the greenhouse.

Table 2. Ion balance of Hoagland and Arnon nutritional solution modified with 0, 60, 120, 180 or $240 \mathrm{mg} \mathrm{Cu} \mathrm{kg}^{-1}$.

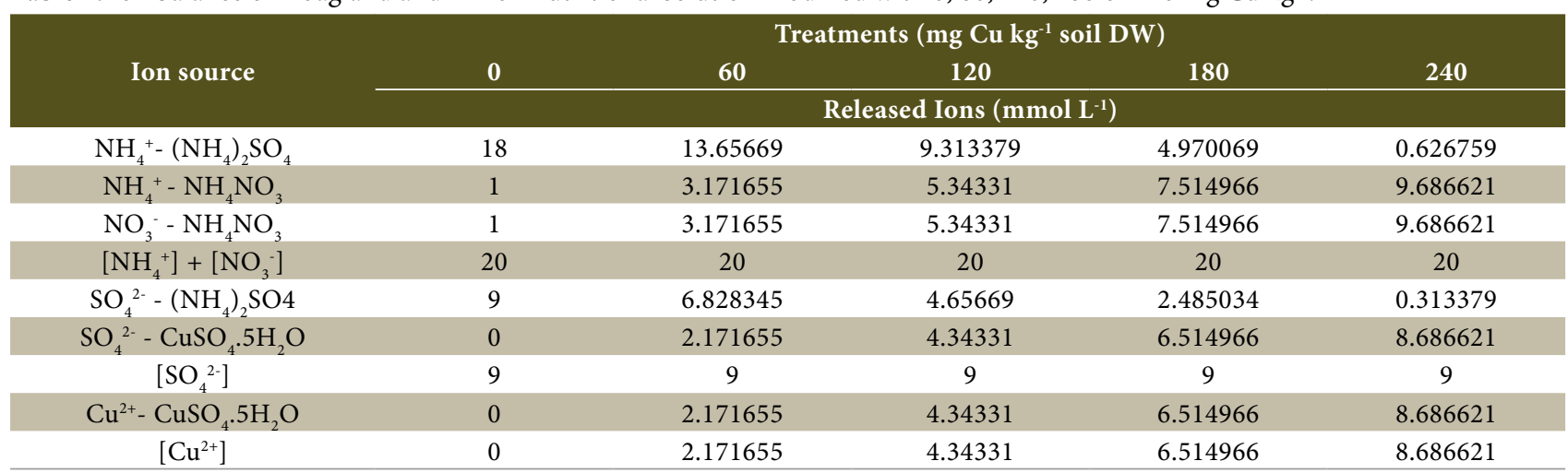




\subsection{Analyses of soil and macro- and micronutrient content in plant tissues}

After the experimental period, soil samples of each treatment were homogenized, fractioned and oven-dried at $60^{\circ} \mathrm{C}$ until constant weight. The $\mathrm{pH}$, total organic matter (O.M.), potential acidity $(\mathrm{H}+\mathrm{Al})$ and content of total macroand micronutrients were determined following the method adopted and described by Raij et al. (2001). Soil pH was potentiometrically determined in $0.01 \mathrm{~mol} \mathrm{~L}^{-1} \mathrm{CaCl}_{2}$. O.M. was determined by the colorimetric method after soil digestion with sulfochromic solution. $\mathrm{H}+\mathrm{Al}$ was determined using $1 \mathrm{~mol} \mathrm{~L}^{-1}$ calcium acetate at $\mathrm{pH}$ 7. Calcium $(\mathrm{Ca})$ and magnesium $(\mathrm{Mg})$ were determined by atomic absorption spectrophotometry (AAS); potassium (K) by flame spectrophotometry; and phosphorus (P) by Ultraviolet-visible (UV/Vis) spectrophotometry after extraction with ion exchange resin. Boron (B) was determined by the colorimetric method (azomethine-H) after extraction with barium chloride. Iron $(\mathrm{Fe})$, manganese $(\mathrm{Mn})$ and zinc (Zn) were determined by atomic absorption spectrometry (AAS) after extraction in DTPA solution at pH 7.3.

Plants were removed from the pots, and the leaves, stems and roots were sectioned. The roots were washed under distilled running water. After oven-drying at $60^{\circ} \mathrm{C}$ until constant weight, the plant material was weighed and milled in a knife mill to obtain a homogeneous powder. The total contents of macroand micronutrients in vegetable material were determined according to the methods described by Malavolta (1997). $\mathrm{Cu}, \mathrm{Ca}, \mathrm{Mg}, \mathrm{Zn}, \mathrm{Fe}$, and $\mathrm{Mn}$ were determined by atomic absorption spectrophotometry (AAS); $\mathrm{P}$ was determined by the ammonium metavanadate colorimetric method; $\mathrm{K}$ was determined by flame spectrophotometry; and sulfur ( $\mathrm{S}$ ) was determined by the turbidimetric method $\left(\mathrm{BaCl}_{2} .2 \mathrm{H}_{2} \mathrm{O}\right)$ after nitric-perchloric acid digestion. Nitrogen $(\mathrm{N})$ was evaluated by the Kjeldahl method after sulfuric digestion, and B was assessed by the colorimetric method (azomethine-H) after incineration.

\subsection{Absolute copper content in tissues}

The absolute copper content ( $\mathrm{mg} \mathrm{Cu} \mathrm{kg}^{-1} \mathrm{DW}$ ) in leaves and roots of S. terebinthifolia and E. uniflora was determined by multiplying the total copper content in each tissue by the tissue’s dry weight (DW) as $\mathrm{Cu}_{\text {tissue }} \mathrm{DW}_{\text {tissue }}$.

\subsection{Statistical analyses}

The experimental design adopted completely randomized blocks, consisting of 5 blocks with 5 treatments and 20 plants per plot, totaling 100 plants of each species. Data were submitted to Shapiro-Wilk normality test and BrownForsythe homoscedasticity test (Tables S1, S2, S3, S4, S5 and S6) using the statistical software GraphPad, v 9.0. If the data were determined to meet assumptions of normality and homogeneity of variance, then they were submitted to analysis of variance (One-Way ANOVA), and means were compared by Tukey's test at $5 \%$ probability $(p \leq 0.05)$. Otherwise, data were submitted to the Kruskal-Wallis nonparametric test, followed by Dunn's multiple comparison test at $5 \%$ probability $(p \leq 0.05)$.

\section{RESULTS}

\subsection{Soil}

O.M. levels in the soil cultivated with E. uniflora showed an increase after treatment with $240 \mathrm{mg} \mathrm{Cu} \mathrm{kg}{ }^{-1}$ when compared to $180 \mathrm{mg} \mathrm{Cu} \mathrm{kg}^{-1}$, while no change in O.M. levels was observed in the soil cultivated with $S$. terebinthifolia (Table 3). No difference was observed for $\mathrm{pH}$ and $\mathrm{H}+\mathrm{Al}$ among treatments in soil cultivated with $S$. terebinthifolia and E. uniflora.

Table 3. Chemical properties of soils cultivated with S. terebinthifolia and E. uniflora. Lowercase letters compare treatments within each species.

\begin{tabular}{|c|c|c|c|c|}
\hline Species & $\begin{array}{l}\text { Treatments } \\
\text { mg Cu kg-1 }^{-1} \\
\text { soil DW }\end{array}$ & $\begin{array}{c}\mathrm{pH} \\
\mathrm{CaCl}_{2}\end{array}$ & $\begin{array}{l}\text { O.M. } \\
\mathrm{g} \mathrm{dm}^{-3}\end{array}$ & $\begin{array}{c}\mathrm{H}+\mathrm{Al} \\
\mathrm{mmol}_{\mathrm{c}} \mathbf{d m}^{-3}\end{array}$ \\
\hline \multirow{5}{*}{ 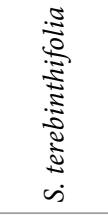 } & 0 & $4.8 \mathrm{a}$ & $40.0 \mathrm{a}$ & $38.6 \mathrm{a}$ \\
\hline & 60 & $4.9 \mathrm{a}$ & $42.4 \mathrm{a}$ & $40.4 \mathrm{a}$ \\
\hline & 120 & $4.9 \mathrm{a}$ & $38.9 \mathrm{a}$ & $39.4 \mathrm{a}$ \\
\hline & 180 & $5.0 \mathrm{a}$ & $41.0 \mathrm{a}$ & $40.1 \mathrm{a}$ \\
\hline & 240 & $5.0 \mathrm{a}$ & $40.0 \mathrm{a}$ & $35.8 \mathrm{a}$ \\
\hline \multirow{5}{*}{ 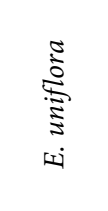 } & 0 & $5.0 \mathrm{a}$ & $40.7 \mathrm{ab}$ & $36.9 \mathrm{a}$ \\
\hline & 60 & $4.9 \mathrm{a}$ & $40.7 \mathrm{ab}$ & $34.2 \mathrm{a}$ \\
\hline & 120 & $5.0 \mathrm{a}$ & $43.4 \mathrm{ab}$ & $38.5 \mathrm{a}$ \\
\hline & 180 & $4.9 \mathrm{a}$ & $38.9 \mathrm{~b}$ & $37.7 \mathrm{a}$ \\
\hline & 240 & $4.9 \mathrm{a}$ & $46.4 \mathrm{a}$ & $37.6 \mathrm{a}$ \\
\hline
\end{tabular}

Means followed by same letters in each column do not differ by Tukey's test at $5 \%$ probability.

The K contents in soil cultivated with S. terebinthifolia decreased after treatment with $240 \mathrm{mg} \mathrm{Cu} \mathrm{kg}^{-1}$ compared to $120 \mathrm{mg} \mathrm{Cu} \mathrm{kg}^{-1}$, but copper-contaminated soil did not affect $\mathrm{K}$ content in the soil cultivated with E. uniflora (Figure 1). No difference was observed for $\mathrm{Ca}$ and $\mathrm{Mg}$ or the micronutrients $\mathrm{B}, \mathrm{Fe}, \mathrm{Mn}$, and $\mathrm{Zn}$ among treatments in soil cultivated with S. terebinthifolia and E. uniflora. 
P

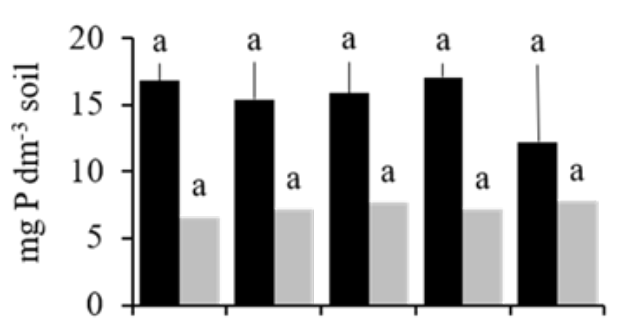

K

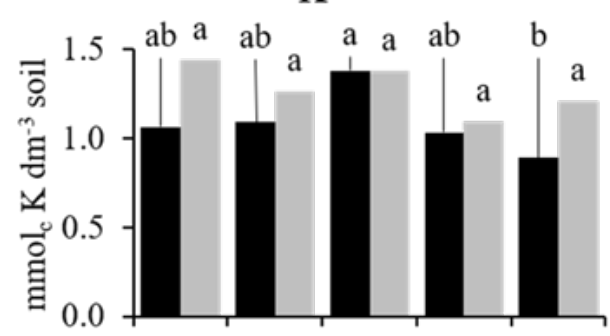

$\mathrm{Ca}$

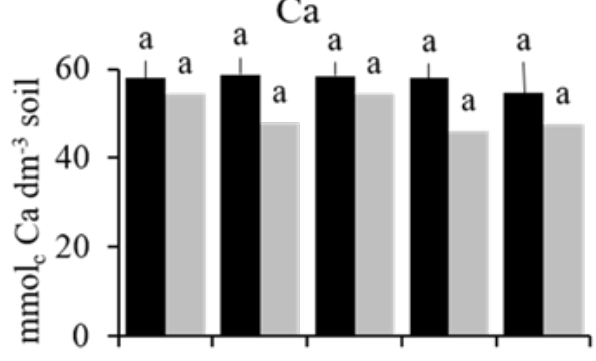

$\mathrm{Mg}$

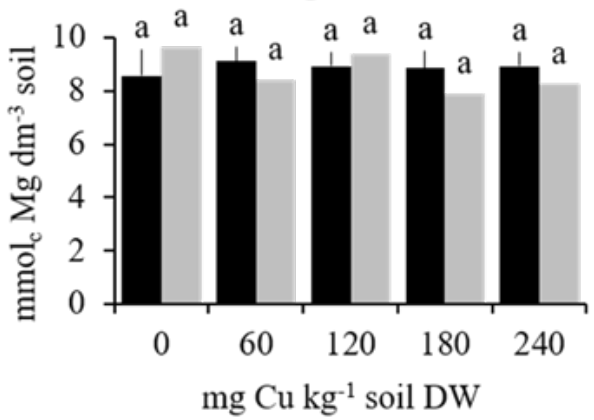

B

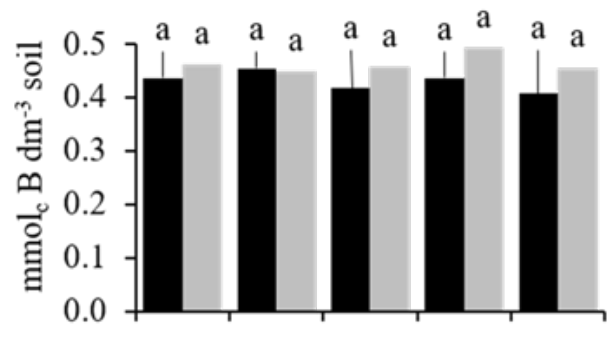

$\mathrm{Fe}$

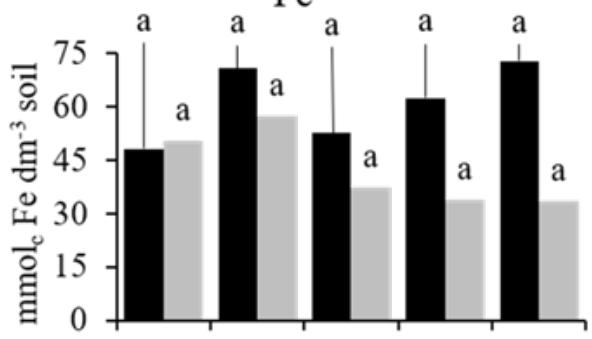

$\mathrm{Mn}$

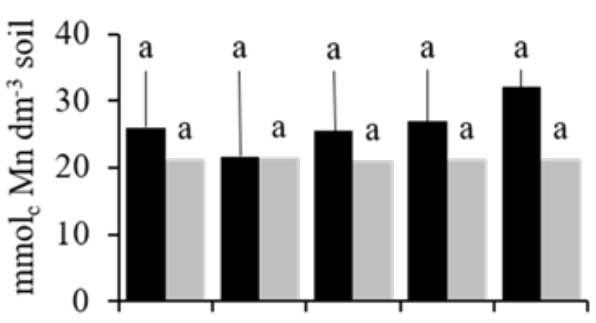

$\mathrm{Zn}$

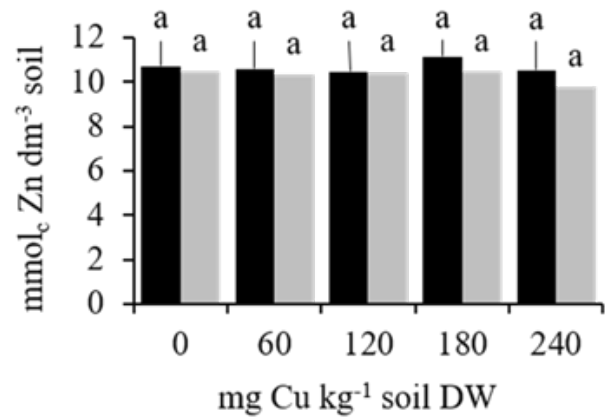

E. uniflora

Figure 1. Nutritional composition of soils cultivated with S. terebinthifolia and E. uniflora. Lowercase letters compare treatments within each species. Means followed by same letters in each column do not differ by parametric Tukey's or non-parametric Dunn's test at $5 \%$ probability.

\subsection{Absolute concentration of copper content in tissues}

The absolute concentration of copper in both species increased as the concentration of copper applied to the soil increased (Figure 2). The absolute concentration of copper in the leaves of S. terebinthifolia varied from 0.025 to 0.028 $\mathrm{mg} \mathrm{Cu} \mathrm{kg}{ }^{-1}$ leaf DW, while in roots, it increased from 0.222 to $0.537 \mathrm{mg} \mathrm{Cu} \mathrm{kg}^{-1}$ root DW (Figure 2a). E. uniflora showed variation in absolute concentration of copper in the leaves from 0.028 to $0.033 \mathrm{mg} \mathrm{Cu} \mathrm{kg}^{-1}$ leaf DW and in the roots from 0.040 to $0.105 \mathrm{mg} \mathrm{Cu} \mathrm{kg}^{-1}$ root DW (Figure 2b). 


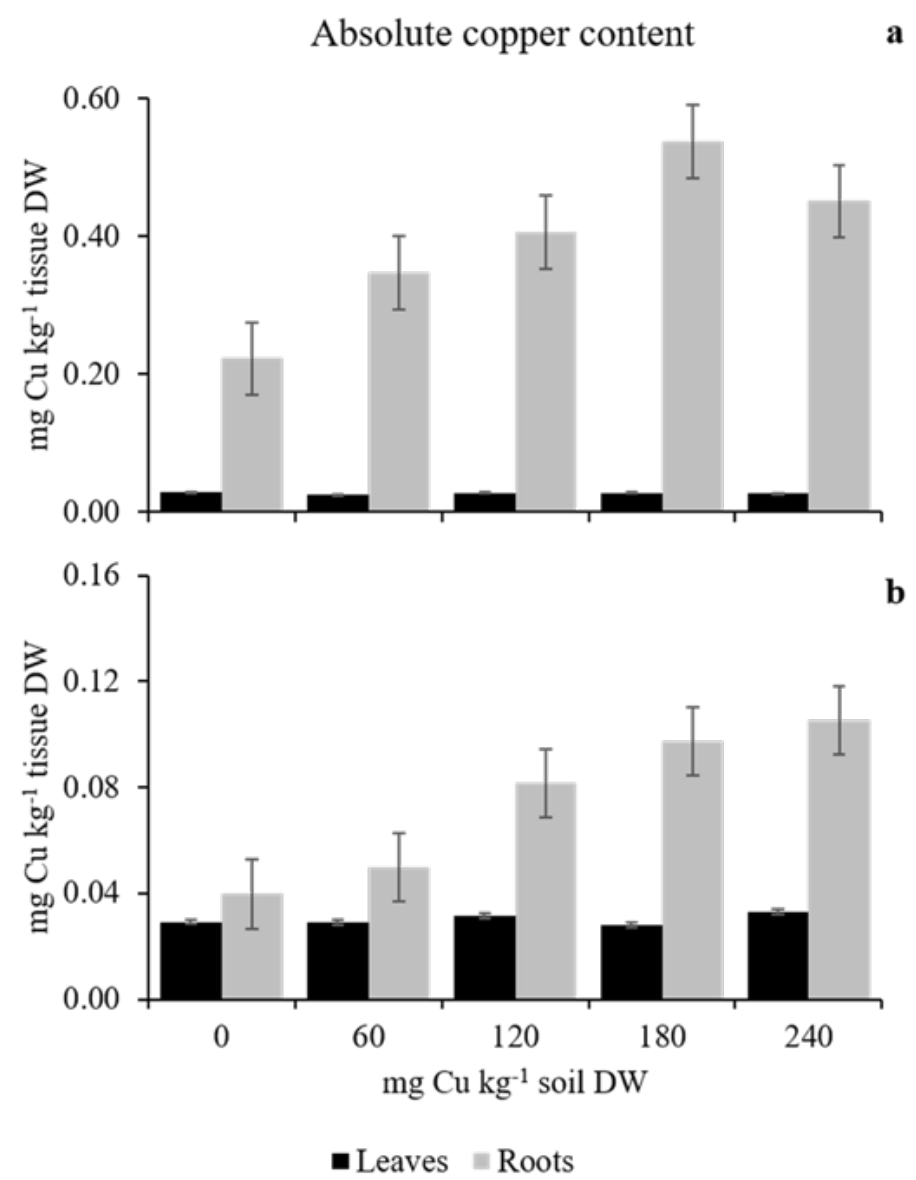

Figure 2. Absolute copper contents in leaves and roots of S. terebinthifolia (a) and E. uniflora (b). Bars represents standard error.

\subsection{Macro- and micronutrient content in plant tissues}

S. terebinthifolia showed a reduction in $\mathrm{N}$ levels in the leaves after treatment with $60 \mathrm{mg} \mathrm{Cu} \mathrm{kg}^{-1}$ when compared to the control, while E. uniflora showed no statistical differences for $\mathrm{N}$ (Figure 3). S. terebinthifolia leaves showed a reduction in K levels after treatment with 60 and $180 \mathrm{mg} \mathrm{Cu} \mathrm{kg}^{-1}$ when compared to the control. E. uniflora leaves also showed a reduction in $\mathrm{K}$ levels after treatment with $180 \mathrm{mg} \mathrm{Cu} \mathrm{kg}^{-1}$ compared to control and $60 \mathrm{mg} \mathrm{Cu} \mathrm{kg}{ }^{-1}$. S. terebinthifolia leaves showed an increase in $\mathrm{Mg}$ levels after treatments with 180 and $240 \mathrm{mg} \mathrm{Cu} \mathrm{kg}^{-1}$ compared to $120 \mathrm{mg} \mathrm{Cu} \mathrm{kg}^{-1}$, but no difference compared to control. No difference was observed for $\mathrm{P}, \mathrm{Ca}, \mathrm{S}, \mathrm{Fe}, \mathrm{B}, \mathrm{Mn}, \mathrm{Zn}$ in S. terebinthifolia and E. uniflora leaves among treatments (Figure 3 ).

E. uniflora roots showed an increase in S levels after treatment with $120 \mathrm{mg} \mathrm{Cu} \mathrm{kg}^{-1}$ compared to $60 \mathrm{mg} \mathrm{Cu} \mathrm{kg}^{-1}$, while no alteration of macro- and micronutrient levels in the roots of S. terebinthifolia among treatments was observed (Figure 4). 
$\mathrm{N}$
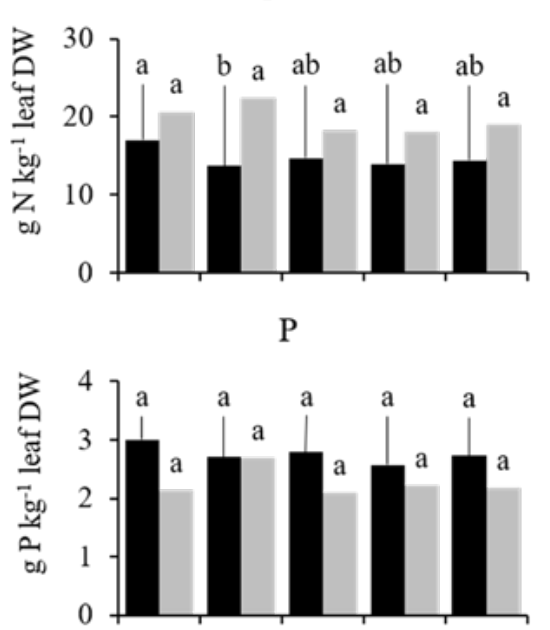

K

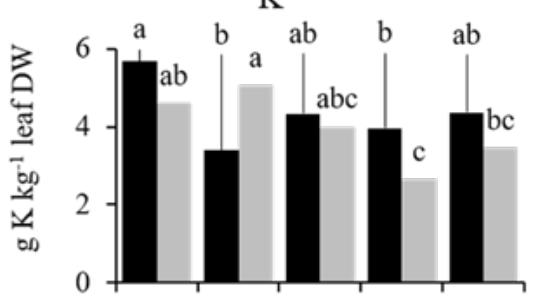

$\mathrm{Ca}$

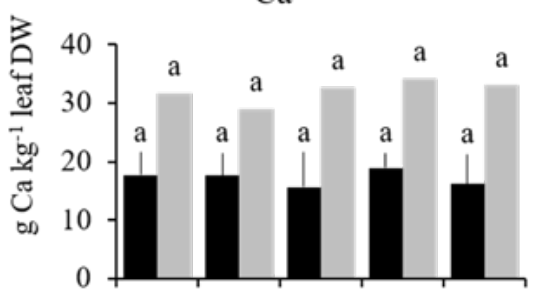

$\mathrm{Mg}$

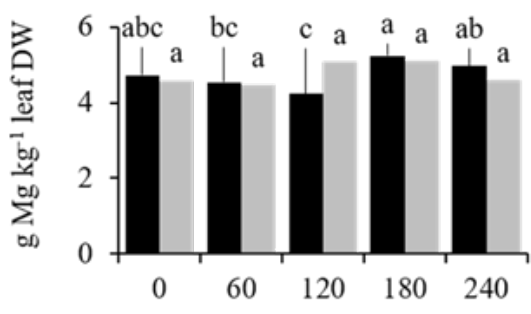

$\mathrm{mg} \mathrm{Cu} \mathrm{kg}{ }^{-1}$ soil DW
$\mathrm{S}$

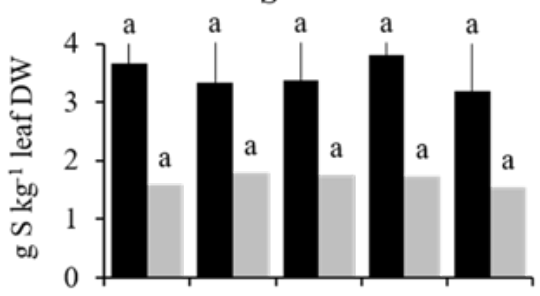

$\mathrm{Fe}$

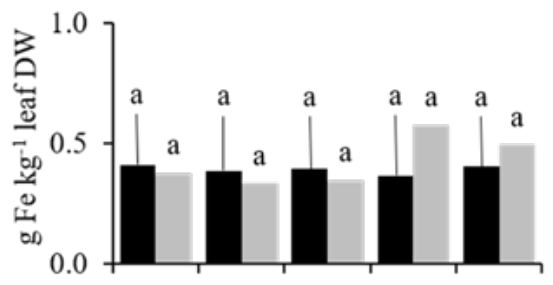

$\mathrm{B}$

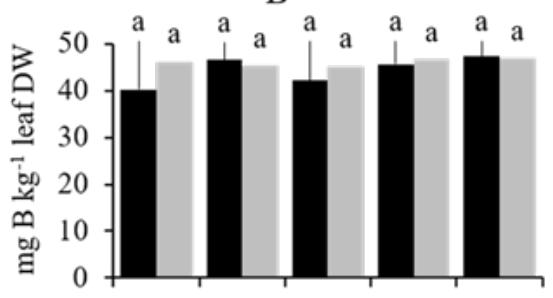

Mn

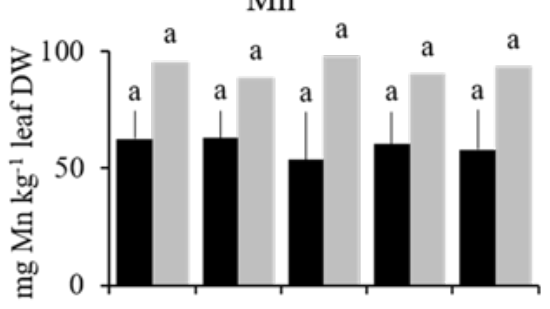

Zn

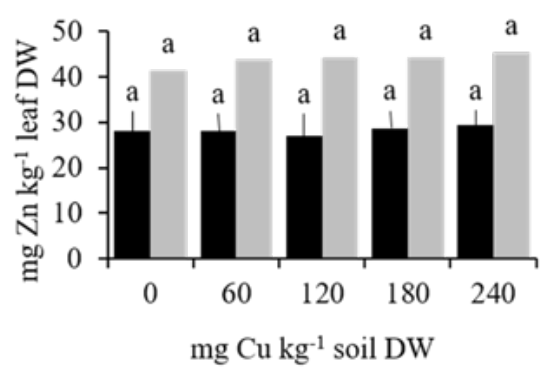

- S. terebinthifolia = E. uniflora

Figure 3. Macro- and micronutrient content in leaves of S. terebinthifolia and E. uniflora. Lowercase letters compare treatments within each species. Means followed by same letters in each column do not differ by Tukey's test at $5 \%$ probability. 

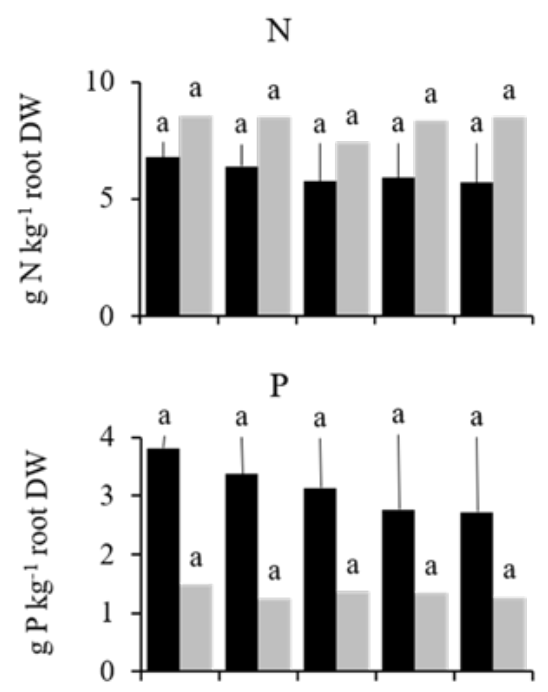

K

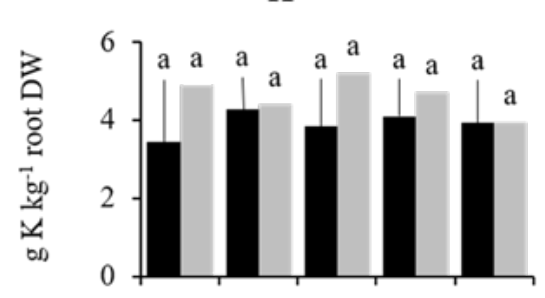

$\mathrm{Ca}$

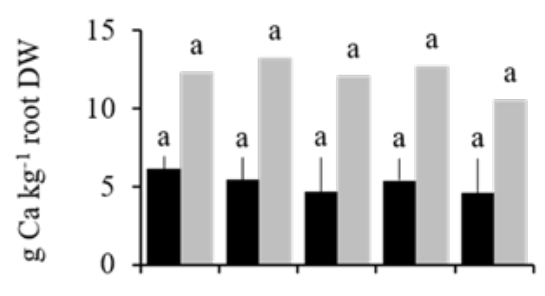

$\mathrm{Mg}$

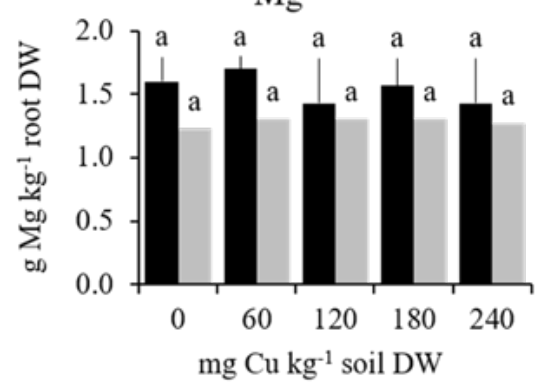

S

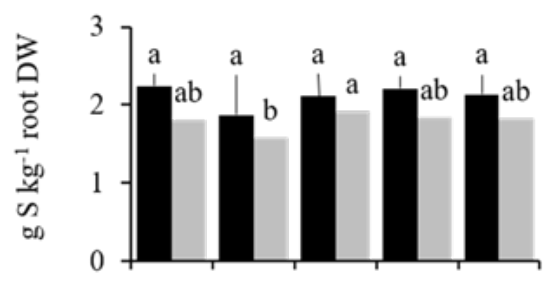

$\mathrm{Fe}$

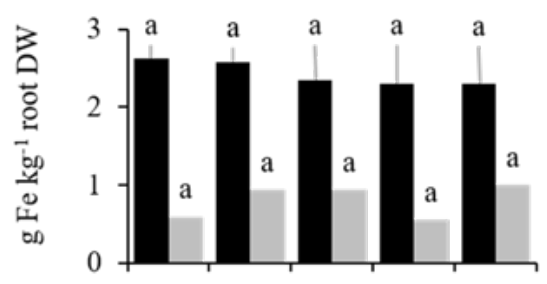

B

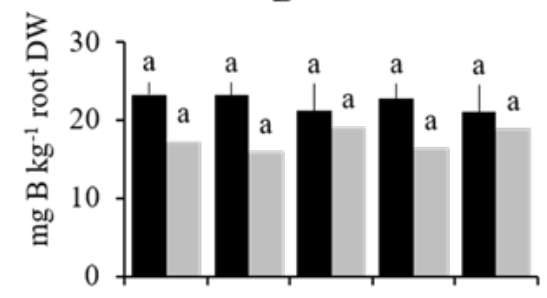

$\mathrm{Mn}$

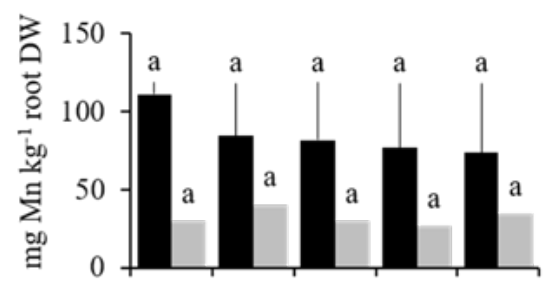

Zn

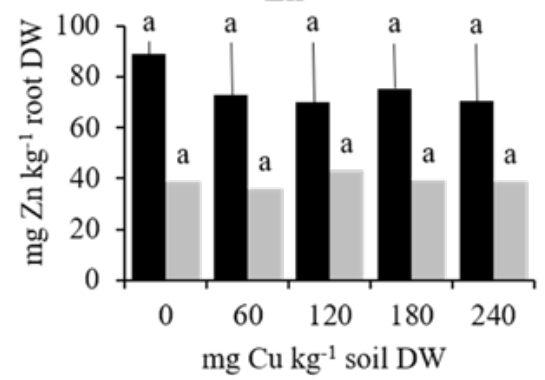

- S. terebinthifolia = E. uniflora

Figure 4. Macro- and micronutrient content in roots of S. terebinthifolia and E. uniflora. Lowercase letters compare treatments within each species. Means followed by same letters in each column do not differ by Tukey's test at $5 \%$ probability. 


\section{DISCUSSION}

Copper contamination can induce different effects on the physicochemical properties of soils (Seguel et al., 2019). Changes in soil characteristics caused by excess of copper result from the effects of copper on the chemical bonds between the soil and the aggregated particles that adhere strongly to O.M., preventing its decomplexation (Karkush \& Ali, 2019). The difference in the contents of O.M. between species is likely related to the heterogeneity of soils from urban forest fragments, which have different levels of O.M. from soil microbiota activities and particulate matter deposition (Ferreira et al., 2019). More specifically, the release of exudates of each species and the chelation of metals in the soil surrounded by plant roots (rhizosphere) can also change nutrient contents and physicochemical characteristics of soils (Campillo-Cora et al., 2019).

Decrease in total $\mathrm{K}$ content in soil caused by excess of copper can be related to competition for adsorption sites in soil particulates (Wyszkowski, 2019), as well as the negative influence of excess copper on the natural cycling of nutrients (Bulbovas et al., 2020). However, the availability of nutrients in copper-contaminated soils is dependent on the plant species present and their uptake capacity (Vendruscolo et al., 2018), as well the release of exudates from each species, which may modify the availability of nutrients in soil (Campillo-Cora et al., 2019). Therefore, the distinct responses in the nutritional status of soil with S. terebinthifolia or E. uniflora is a result of the difference between species uptake capacity and nutrient availability.

The copper we added to the soil was effectively uptake by S. terebinthifolia and E. uniflora roots and incorporated into plant tissues, mostly accumulated in the root system. Copper uptake by roots is carried out through several specific and non-specific carriers of heavy metals located in the plasma membrane of root cells (Printz et al., 2016). Copper naturally has a strong affinity for groups of enzymes and proteins present in the apoplast and cell wall of root cells, promoting its retention in plant roots (Girotto et al., 2016). In addition, under situations of toxicity and excess of copper, several species of plants have physiological mechanisms of tolerance to heavy metals, such as release of exudates by the roots, as well as chelation, sequestration and compartmentalization of metal ions in the vacuoles of root cells (Kumar et al., 2020). The increase in copper concentration in tissues, with preferential accumulation in the roots of S. terebinthifolia and E. uniflora, is a defense response for these tree species, restricting heavy metal to the roots and preventing translocation to leaves and causing a negative impact on the photosynthetic efficiency of plants (Marques et al., 2018).
Heavy metal stress can cause disturbances in the regulation of $\mathrm{N}$ uptake by roots and its translocation to shoots, leading to a decrease in the total $\mathrm{N}$ levels in leaves (Hippler et al., 2018). Toxicity produced by excess of $\mathrm{Cu}$ in plants reduces $\mathrm{N}$ uptake and translocation by decreasing the expression level of genes encoding $\mathrm{NO}_{3}{ }^{-}$transporters (Huo et al., 2020). The changes in $\mathrm{K}$ levels could be triggered by an impairment in uptake and translocation of $\mathrm{K}$ from roots to leaves as a result of copper toxicity. $\mathrm{Cu}$ toxicity induces the reduction of macronutrient content in shoot (i.e., $\mathrm{K}$ ) as a result of interferences from ion uptake and translocation from root to shoot (Marastoni et al., 2019), producing an imbalance in homeostasis and distribution of nutrients throughout the plant (Souza et al., 2014; Zaouali et al., 2020). Furthermore, since cationic transporters can act in the transport of different ions in a nonspecific way, a decrease in potassium concentration $\left(\mathrm{K}^{+}\right)$in the aerial part of plants may be related to $\mathrm{K}$ in competition with copper ions $\left(\mathrm{Cu}^{+}\right.$and $\left.\mathrm{Cu}^{2+}\right)$ in the translocation processes (Cao et al., 2017; Kobayashi et al., 2019). Excess of copper can induce an increase of $\mathrm{Mg}$ translocation from roots to leaves, thus maintaining the homeostasis of mineral composition in shoots (Zeng et al., 2019). With enough concentration of Mg in plant tissues, the effects of excess $\mathrm{Cu}$ caused by the ionic competition between elements can be mitigated, preventing excess $\mathrm{Cu}$ from binding to vital action sites and causing toxicity (Juang et al., 2014).

$\mathrm{Cu}$ toxicity can also cause impairment in nutrient uptake by roots by the competition among ions for uptake and nutritional imbalance as a consequence of saturation of nonspecific ionic transporters (Freitas et al., 2015). However, these effects are highly dependent on copper concentrations and method of cultivation. For example, plants cultivated in nutritive solutions have higher copper toxicity by the elevated availability of elements and fast uptake by the roots (Mezzavilla \& Neto, 2017,), while plants grown in soils present lower copper uptake by the strong adhesion of copper to soil particles and a host of soil-system biotic and abiotic relationships that can lead to less adverse effects on nutritional balance (Kelepertzis et al., 2015; Chua et al., 2019). Since our study was carried out with soil, it is possible that copper remained partially aggregated to the soil, suggesting that the concentrations uptake by both tree species were insufficient to cause nutritional imbalance in all measured elements. It is also possible that higher doses or longer exposure to $\mathrm{Cu}$ could have increased the amount uptake by roots, causing nutritional imbalances and negatively interfering with the homeostasis of more elements. In addition to factors related to experimental condition, copper effects on the nutritional imbalance in plants are associated with synergism and/or competition between copper and mineral nutrients for specific absorption sites and transporters (Printz et al., 2016), and some nutrients have weak competition against 
copper as a result of different ionic characteristics and lack of affinity with the same carriers (Andrés-Bordería et al., 2017). Thus, the concentration and translocation of the unaffected elements may be a consequence of their weak competition with copper for specific absorption sites and carriers (Kobayashi et al., 2019). The irregular responses in nutrient concentration of S. terebinthifolia and E. uniflora to copper stress can also be explained by the fact that different species grown in coppercontaminated soils present different dynamics of accumulation, transport, and nutritional homeostasis in relation to their uptake capacity and the rate of development for each tissue (Zeng et al., 2019; Zabotto et al., 2020). Furthermore, a variety of tolerance mechanisms and strategies are adopted by plants which can result in distinct nutritional imbalances for each species when cultivated in copper-contaminated soils (Yruela, 2009).

In our study, we observed that excess copper can modify the chemical properties of urban forest fragment soil. However, the magnitude of these changes can be affected by the species inhabiting that soil. Moreover, when cultivated in soils with high concentrations of copper, we found that the level of nutrients of $S$. terebinthifolia and E. uniflora can be affected in different ways. For instance, while the pioneer species S. terebinthifolia presents nutritional imbalance only in the leaves, the non-pioneer species E. uniflora presents nutritional imbalance in both leaves and roots. During the experiment, a small number of characteristics of soil and plant nutrition were altered. Therefore, it can be assumed that the applied dose or time was insufficient to cause major nutrient imbalance, but that larger doses or longer cultivation time could possibly result in more significant nutritional imbalance. We conclude that the excess of copper can change the chemical and nutritional characteristics of soil, as well as the nutritional dynamics of Schinus terebinthifolia and Eugenia uniflora seedlings.

\section{ACKNOWLEDGEMENTS}

We thank the Fundação de Amparo à Pesquisa do Estado de São Paulo (FAPESP) for financial support. This work was supported by Fundação de Amparo à Pesquisa do Estado de São Paulo [FAPESP] under Grant [proc. 2017/50341-0] and M.C.S Master's scholarship was supported by FAPESP under Grant [proc. 2019/03105-4].

\section{SUBMISSION STATUS}

Received: 11 May. 2021

Accepted: 24 Sep. 2021

Associate editor: Eduardo Vinicius Silva

\section{CORRESPONDENCE TO}

\section{Armando Reis Tavares}

Instituto de Botânica de São Paulo, Avenida Miguel Stefano, 3687, CEP 04301-902, São Paulo, SP, Brasil.

e-mail: atavares2005@yahoo.com.br

\section{AUTHORS' CONTRIBUTIONS}

Matheus Casarini Siqueira: Formal analysis (Equal); Data collection (Equal); Investigation (Equal); Validation (Supporting); Writing-original draft (Equal); Writing-review \& Editing (Equal).

Shoey Kanashiro: Investigation (Supporting); Methodology (Equal); Validation (Supporting); Writing-review \& Editing (Equal).

Marisa Domingos Investigation (Equal); Funding acquisition (Equal); Project Administration (Equal); Methodology (Equal); Validation (Equal); Writing-review \& Editing (Equal).

Mirian Cilene Spasiani Rinaldi: Investigation (Supporting); Methodology (Equal); Validation (Equal); Writing-review \& Editing (Equal).

Armando Reis Tavares: Investigation (Equal); Funding acquisition (Supporting); Project Administration (Equal); Methodology (Equal); Supervision (Equal); Validation (Equal); Writing-review \& Editing (Equal).

\section{SUPPLEMENTARY MATERIAL}

The following online material is available for this article: Table S1 - Shapiro-Wilk Normality test, Brown-Forsythe Heteroscedasticity test and ANOVA table of chemical and nutritional data of soil cultivated with Schinus terebinthifolia. Table S2 - Shapiro-Wilk Normality test, Brown-Forsythe Heteroscedasticity test and ANOVA table of chemical and nutritional data of soil cultivated with Schinus terebinthifolia. Table S3 - Shapiro-Wilk Normality test, Brown-Forsythe Heteroscedasticity test and ANOVA table of Schinus terebinthifolia leaf nutritional data.

Table S4 - Shapiro-Wilk Normality test, Brown-Forsythe Heteroscedasticity test and ANOVA table of Eugenia uniflora leaf nutritional data.

Table S5 - Shapiro-Wilk Normality test, Brown-Forsythe Heteroscedasticity test and ANOVA table of Schinus terebinthifolia root nutritional content.

Table S6 - Shapiro-Wilk Normality test, Brown-Forsythe Heteroscedasticity test and ANOVA table of Eugenia uniflora leaf nutritional content. 


\section{REFERENCES}

Adrees M, Ali S, Rizwan M, Ibrahim M, Abbas F, Farid M, Ziaur-Rehman M, Irshad MK, Bharwana SA. The effect of excess copper on growth and physiology of important food crops: a review. Environmental Science and Pollution Research 2015; 22:8148-8162. doi:10.1007/s11356-015-4496-5.

Andrés-Bordería A, Andrés F, Garcia-Molina A, Perea-García A, Domingo C, Puig S Peñarrubia L. Copper and ectopic expression of the Arabidopsis transport protein COPT1 alter iron homeostasis in rice (Oryza sativa L.). Plant Molecular Biology 2017; 95:17-32. doi:10.1007/s11103-017-0622-8.

Argyraki A, Kelepertzis E, Botsou F, Paraskevopoulou V, Katsikis I, Trigoni M. Environmental availability of trace elements ( $\mathrm{Pb}, \mathrm{Cd}, \mathrm{Zn}$, $\mathrm{Cu}$ ) in soil from urban, suburban, rural and mining areas of Attica, Hellas. Journal of Geochemical Exploration 2018; 187:201-213. doi:10.1016/j.gexplo.2017.09.004.

Bulbovas P, Camargo CZ, Ferreira ML, Domingos M. Anthropic interferences in the nutritional status of tree species growing in urban and peri-urban Atlantic forest remnants. Urban Forestry \& Urban Greening 2020; 50:126642. doi:10.1016/j.ufug.2020.126642.

Campillo-Cora C, Fernández-Calviño D, Pérez-Rodríguez P, Fernández-Sanjurjo MJ, Núñez-Delgado A, Álvarez-Rodríguez E, Arias-Estévez M, Nóvoa-Muñoz JC. Copper and zinc in rhizospheric soil of wild plants growing in long-term acid vineyard soils. Insights on availability and metal remediation. Science of The Total Environment 2019; 672:389-399. doi:10.1016/j.scitotenv.2019.03.301.

Cao Y, Ma C, Chen G, Zhang J, Xing B. Physiological and biochemical responses of Salix integra Thunb. under copper stress as affected by soil flooding. Environmental Pollution 2017; 225:644-653. doi:10.1016/j.envpol.2017.03.040.

CETESB (Companhia Ambiental Do Estado De São Paulo) Valores orientadores para solo e água subterrânea no estado de São Paulo. Diário Oficial Estado de São Paulo - Caderno Executivo I (Poder Executivo, Seção I) 2016; 126, 55-56.

Chua J, Banua JM, Arcilla I, Orbecido A, Castro ME, Ledesma N, Belo L. Phytoremediation potential and copper uptake kinetics of Philippine bamboo species in copper contaminated substrate. Heliyon 2019; 5:e02440. doi:10.1016/j.heliyon.2019.e02440.

Dislich R, Pivello VR. Tree structure and species composition changes in an urban tropical forest fragment (São Paulo, Brazil) during a five-year interval. Boletim de Botânica da Universidade de São Paulo 2002; 20:1-12.

Farias JG, Nunes ST, Sausen D, Nunes MA, Neis FA, Garlet LC, Nunes PAA, Dressler VL, Schetinger MRC, Rossato LV, Girotto E, Brunetto G, Nicoloso FT. Agricultural contamination: Effect of copper excess on physiological parameters of potato genotypes and food chain security. Journal of Applied Botany and Food Quality 2018; 91:249-259. doi:10.5073/JABFQ.2018.091.033.

Ferreira ML, Andrade NGV, Costa MCLD, Araujo DM, Côrtes PL, Quaresma CC, Conit DM, Camargo PB. Soil fertility and litterfall assessment in a peri-urban forest of São Paulo, SP: understanding for urban green areas manegement. Holos 2019; 35:1-16. doi:10.15628/ holos.2019.8290.
Freitas TA, França MGC, Almeida AAF, Oliveira SJR, Jesus RM, Souza VL, Silva JVS, Mangabeira PA. Morphology, ultrastructure and mineral uptake is affected by copper toxicity in young plants of Inga subnuda subs. luschnathiana (Benth.) TD Penn. Environmental Science and Pollution Research 2015; 22:15479-15494. doi:10.1007/ s11356-015-4610-8.

Girotto E, Ceretta CA, Rossato LV, Farias JG, Brunetto G, Miotto A, Tiecher TL, Conti L, Lourenzi CR, Schmatz R, Giachini A. Nicoloso FT. Biochemical changes in black oat (Avena strigosa Schreb) cultivated in vineyard soils contaminated with copper. Plant Physiology and Biochemistry 2016; 103:199-207. doi:10.1016/j. plaphy.2016.02.030.

Hippler FWR, Mattos Jr. D, Boaretto RM, Williams LE. Copper excess reduces nitrate uptake by Arabidopsis roots with specific effects on gene expression. Journal of Plant Physiology 2018; 228:158-165. doi:10.1016/j.jplph.2018.06.005.

Hoagland D, Arnon DI. The water culture method for growing plants without soil. Berkeley. California Agricultural Experiment Station Press; 1950.

Hossain MS, Abdelrahman M, Tran CD, Nguyen KH, Chu HD, Watanabe Y, Hasanuzzaman M, Mohsin SM, Fujita M, Tran LSP. Insights into acetate-mediated copper homeostasis and antioxidant defense in lentil under excessive copper stress. Environmental Pollution 2020; 258:113544. doi:10.1016/j.envpol.2019.113544.

Hu C, Liu L, Li X, Xu Y, Ge Z, Zhao Y. Effect of graphene oxide on copper stress in Lemna minor L.: evaluating growth, biochemical responses, and nutrient uptake. Journal of Hazardous Materials 2018; 341:168-176. doi:10.1016/j.jhazmat.2017.07.061.

Huo K, Shangguan X, Xia Y, Shen Z, Chen C. Excess copper inhibits the growth of rice seedlings by decreasing uptake of nitrate. Ecotoxicology and Environmental Safety 2020; 190:110105. doi:10.1016/j.ecoenv.2019.110105.

Juang KW, Lee YI, Lai HY, Chen BC. Influence of magnesium on copper phytotoxicity to and accumulation and translocation in grapevines. Ecotoxicology and Environmental Safety 2014; 104:36-42. doi:10.1016/j.ecoenv.2014.02.008.

Karkush MO, Ali SD. Effects of copper sulfate contamination on the geotechnical behavior of clayey soils. Journal of GeoEngineering 2019; 14:47-52. doi:10.6310/jog.201903_14(1).6.

Kelepertzis E, Paraskevopoulou V, Argyraki A, Fligos G, Chalkiadaki O. Evaluation of single extraction procedures for the assessment of heavy metal extractability in citrus agricultural soil of a typical Mediterranean environment (Argolida, Greece). Journal of Soils and Sediments 2015; 15:2265-2275. doi:10.1007/s11368-015-1163-x.

Kobayashi R, Kobayashi NI, Tanoi K, Masumori M, Tange T. Potassium supply reduces cesium uptake in Konara oak not by an alteration of uptake mechanism, but by the uptake competition between the ions. Journal of Environmental Radioactivity 2019; 208:106032. doi:10.1016/j.jenvrad.2019.106032.

Kumar V, Pandita S, Sidhu GPS, Sharma A, Khanna K, Kaur P, Bali AS, Setia R. Copper bioavailability, uptake, toxicity and tolerance in plants: a comprehensive review. Chemosphere 2020; 262:127810. doi:10.1016/j.chemosphere.2020.127810. 
Laurent C, Bravin MN, Crouzet O, Pelosi C, Tillard E, Lecomte $\mathrm{P}$, Lamy I. Increased soil $\mathrm{pH}$ and dissolved organic matter after a decade of organic fertilizer application mitigates copper and zinc availability despite contamination. Science of the Total Environment 2019; 709:135927. doi:10.1016/j.scitotenv.2019.135927.

Li C, Zhou K, Qin W, Tian C, Qi M, Yan X, Han W. A review on heavy metals contamination in soil: effects, sources, and remediation techniques. Soil and Sediment Contamination: An International Journal 2019; 28:380-394. doi:10.1080/15320383.2019.1592108.

Li Q, Chen HH, Qi YP, Ye X, Yang LT, Huang ZR, Chen, LS. Excess copper effects on growth, uptake of water and nutrients, carbohydrates, and PSII photochemistry revealed by OJIP transients in Citrus seedlings. Environmental Science and Pollution Research 2019; 26(29):30188-30205. doi:10.1007/s11356-019-06170-2.

Malavolta E Avaliação do estado nutricional das plantas. Piracicaba. POTAFOS; 1997.

Marastoni L, Sandri M, Pii Y, Valentinuzzi F, Brunetto G, Cesco S, Mimmo T. Synergism and antagonisms between nutrients induced by copper toxicity in grapevine rootstocks: monocropping vs. intercropping. Chemosphere 2019; 214:563-578. doi:10.1016/j. chemosphere.2018.09.127.

Marco R, Silva RF, Andreazza R, RosCO, Scheid DL, Bertollo GM. Copper phytoaccumulation and tolerance by seedlings of native Brazilian trees. Environmental Engineering Science 2016; 33(3):176184. doi:10.1089/ees.2015.0307.

Marques DM, Júnior VV, Silva AB, Mantovani JR, Magalhães PC, Souza TC. Copper toxicity on photosynthetic responses and root morphology of Hymenaea courbaril L. (Caesalpinioideae). Water, Air, \& Soil Pollution 2018; 229:138. doi:10.1007/s11270-018-3769-2.

Mezzavilla NV, Neto JJ. Avaliação do desenvolvimento de plântulas de aroeira (Schinus terebinthifolius R.) em diferentes concentrações de alumínio. Semioses 2017; 11:9-18. doi:10.15202/1981996x.2017v11n3p9.

Nakazato RK, Lourenço IS, Esposito MP, Lima ME, Ferreira ML, Campos OAR, Rinaldi MCS, Domingos M. Trace metals at the treelitter-soil-interface in Brazilian Atlantic Forest plots surrounded by sources of air pollution. Environmental Pollution 2021; 268: 115797. doi:10.1016/j.envpol.2020.115797.

Printz B, Lutts S, Hausman JF, Sergeant K. Copper trafficking in plants and its implication on cell wall dynamics. Frontiers in Plant Science 2016; 7:601. doi:10.3389/fpls.2016.00601.

Raij BV, Andrade JC, Cantarella H, Quaggio JA. Análise química para avaliação da fertilidade de solos tropicais. Campinas. IAC; 2001.

Rehman M, Liu L, Wang Q, Saleem MH, Bashir S, Ullah S, Peng D. Copper environmental toxicology, recent advances, and future outlook: A review. Environmental Science and Pollution Research 2019; 26:18003-16. doi: 10.1007/s11356-019-05073-6.

Saleem MH, Fahad S, Khan SU, Din M, Ullah A, Sabagh AE, Liu L. Copper-induced oxidative stress, initiation of antioxidants and phytoremediation potential of flax (Linum usitatissimum L.) seedlings grown under the mixing of two different soils of China. Environmental Science and Pollution Research 2020; 27:5211-5221. doi:10.1007/s11356-019-07264-7.

Santos HG, Jacomine PKT, Anjos LHC, Oliveira VA, Lumbreras JF, Coelho MR, Almeida JA, Araujo Filho JC, Oliveira JB, Cunha TJF. Sistema brasileiro de classificação de solos. Brasília. Embrapa; 2018.

Seguel CG, Muñoz H, Segovia J, Ávalos B, Martín JR. Assessment of soil contamination in Caleta Vitor and surrounding areas, northern Chile, due to heavy metal enrichment caused by an abandoned copper mine. Interciencia 2019; 44:241-246.

Shabbir Z, Sardar A, Shabbir A, Abbas G, Shamshad S, Khalid S, Natasha, Murtaza G, Dumat C, Shahid M. Copper uptake, essentiality, toxicity, detoxification and risk assessment in soilplant environment. Chemosphere 2020; 259:127436. doi:10.1016/j. chemosphere.2020.127436.

Siqueira MC, Kanashiro S, Domingos M, Rinaldi MCS, Tavares AR. Physiological and biochemical changes in tree seedlings growing in urban forest soil contaminated with copper in São Paulo, Brazil. Plant and Soil 2021; 464:149-163. doi:10.1007/s11104-021-04948-3.

Souza VL, Almeida AAF, Souza JDS, Mangabeira PA, Jesus RM, Pirovani CP, Ahnert D, Baligar DC, Loguercio LL. Altered physiology, cell structure, and gene expression of Theobroma cacao seedlings subjected to $\mathrm{Cu}$ toxicity. Environmental Science and Pollution Research 2014; 21:1217-1230. doi: 10.1007/s11356-013-1983-4.

Vendruscolo D, Santana NA, Souto KM, Ferreira PA, Melo GWBD, Jacques RJS. Differential behavior of the summer cover crops in the absorption and translocation of copper. Ciência Rural 2018; 48:e20180005. doi:10.1590/0103-8478cr20180005.

Wyszkowski M. Soil Contamination with copper and its effect on selected soil properties after applying neutralizing substances. Polish Journal of Environmental Studies 2019; 28:2465-2471. doi:10.15244/pjoes/90357.

Yruela I. Copper in plants: acquisition, transport and interactions. Functional Plant Biology 2009; 36:409-430. doi:10.1071/FP08288.

Zabotto AR, França WS, Domingos M, Rinaldi MCS, Kanashiro S, Ferreira ML, Tavares AR. Copper accumulation and distribution in two arboreal species of the atlantic forest. Floresta e Ambiente 2020; 27:e20190027. doi:10.1590/2179-8087.002719.

Zaouali W, Mahmoudi H, Salah IB, Mejri F, Casabianca H, Hosni K, Ouerghi Z. Copper-induced changes in growth, photosynthesis, antioxidative system activities and lipid metabolism of cilantro (Coriandrum sativum L.). Biologia 2020; 75:367-380. doi:10.2478/s11756-020-00419-9

Zeng Q, Ling Q, Wu J, Yang Z, Liu R, Qi Y. Excess copper-induced changes in antioxidative enzyme activity, mineral nutrient uptake and translocation in sugarcane seedlings. Bulletin of Environmental Contamination and Toxicology 2019; 103:834-840. doi:10.1007/ s00128-019-02735-6. 